\title{
Free acetylcholine in the cerebrospinal fluid after brain operations
}

\author{
A. SAHAR ${ }^{1}$ \\ From the Department of Neurosurgery, Rothschild-Hadassah University Hospital, Jerusalem, Israel
}

Bornstein (1946) demonstrated the presence of free acetylcholine in the cerebrospinal fluid of animals subjected to experimental head injury. Later, - Tower and McEachern (1948) and Sachs (1957) showed the same in patients suffering from concussion of the brain. Tower and McEachern also demonstrated a correlation between the level of acetylcholine, changes in E.E.G. pattern, and the clinical state of patients with head injury. Consequently, anticholinergic drugs were used successfully in the treatment of closed head injury (Ward, 1950; Ruge, 1954; Jenkner, 1956; Heppner and Diemath, 1958; Baldauf and Göhring, 1960) as proposed by Bornstein in his original work.

There are certain common features in the clinical picture of concussion and the state of patients after intracranial operations. We proposed to find out whether acetylcholine could be demonstrated in the cerebrospinal fluid after operations, and also whether any correlation could be found between the level of acetylcholine and the degree and duration of impaired consciousness in the post-operative patient.

MATERIAL AND METHODS

Thirty cats weighing 3 to $4 \mathrm{~kg}$. were used. Under intravenous Nembutal anaesthesia a piece of brain tissue measuring $15 \times 15 \times 4 \mathrm{~mm}$. was removed from the right fronto-parietal region. Haemostasis was secured by cauterization and Gelfoam. Twenty to 30 minutes after operation cerebrospinal fluid was drawn by cisternal puncture.

For controls, samples of cerebrospinal fluid were taken from five similarly anaesthetized tut not operated cats.

Cerebrospinal fluid was drawn by lumbar puncture from 20 patients 30 minutes to one hour after various intracranial operations. From five of these patients samples of cerebrospinal fluid were also taken before the operation when the patients were already under anaesthesia.

For control of the effects of anaesthesia, samples of cerebrospinal fluid were taken during operation from 10 patients with herniated intervertebral disc.

As a further control, acetylcholine determinations

'Supported by a grant from the Hadassah-Hebrew University Research Fund were also made on cerebrospinal fluid of 40 patients with neurological diseases not treated surgically.

Acetylcholine was determined by biological assay, using the small intestine of the guinea-pig. A segment of intestine was suspended in a $12 \mathrm{ml}$. organ bath in TyrodeRinger solution at $37^{\circ} \mathrm{C}$. to which the samples of cerebrospinal fluid were added. The acetylcholine level recorded was the average of three determinations. Proof that the substance causing contraction of the intestine was actually acetylcholine was obtained by blocking its action by atropine.

Samples of cerebrospinal fluid containing even traces of blood were discarded.

\section{RESULTS}

ACETYLCHOLINE IN CEREBROSPINAL FLUID OF CATS Acetylcholine was demonstrated in the cerebrospinal fluid of all animals subjected to operation (Table I). The average level found was $8.4 \gamma$ per $100 \mathrm{ml}$. In only one of the control animals (anaesthesia without operation) was any measurable acetylcholine found in the cerebrospinal fluid.

TABLE I

ACETYLCHOLINE IN CEREBROSPINAL FLUID OF EXPERIMENTAL ANIMALS

\begin{tabular}{|c|c|c|c|}
\hline \multicolumn{2}{|c|}{ Operated Animals } & \multicolumn{2}{|c|}{ Controls } \\
\hline $\begin{array}{l}\text { No. of } \\
\text { Cats }\end{array}$ & $\begin{array}{l}\text { Acetylcholine Level } \\
(\gamma / 100 \mathrm{ml} .)\end{array}$ & $\begin{array}{l}\text { No. of } \\
\text { Cats }\end{array}$ & $\begin{array}{l}\text { Acetylcholine Leve } \\
(\gamma / 100 \mathrm{ml} .)\end{array}$ \\
\hline $\begin{array}{c}3 \\
18(60 \%) \\
9(30 \%) \\
\text { Average } \\
\text { Extremes }\end{array}$ & $\begin{array}{c}<3 \\
4-8 \\
>10 \\
8 \cdot 4 \\
1 \cdot 0-29\end{array}$ & $\begin{array}{l}4 \\
1\end{array}$ & $\begin{array}{l}\mathbf{0} \\
\mathbf{2}\end{array}$ \\
\hline
\end{tabular}

ACETYLCHOLINE IN CEREBROSPINAL FLUID OF PATIENTS WITH NEUROLOGICAL DISEASE NOT OPERATED ON The group of $\mathbf{4 0}$ patients included cases of cerebrovascular accident, brain atrophy, multiple sclerosis, idiopathic epilepsy, lues, polyneuritis. In 15 of the patients no acetylcholine could be demonstrated in the cerebrospinal fluid; this group included all cases of multiple sclerosis, brain atrophy, and lues. In the remaining 25 patients the level of acetylcholine was $0.6-5.5 \gamma$ per $100 \mathrm{ml}$., the average 
being $2 \gamma$. Levels higher than $4 \gamma$ per $100 \mathrm{ml}$. were found in two cases of polyneuritis (during the acute stage), in two patients during status epilepticus, and in one case of leucoencephalitis.

ACETYLCHOLINE IN CEREBROSPINAL FLUID OF PATIENTS AFTER BRAIN OPERATIONS All but one of the patients who underwent intracranial operations showed elevated acetylcholine levels in the cerebrospinal fluid post-operatively (Table II), the average level being $5 \gamma$ per $100 \mathrm{ml}$. Of the cases in which acetylcholine was determined both pre- and postoperatively, in four there was a definite rise after the operation. In the fifth case no acetylcholine was found in the cerebrospinal fluid either before or after operation.
TABLE II

ACETYLCHOLINE IN CEREBROSPINAL FLUID OF OPERATED PATIENTS

\begin{tabular}{|c|c|c|c|}
\hline \multicolumn{2}{|c|}{ Post-operative Patients } & \multicolumn{2}{|c|}{ Pre-operative Patients } \\
\hline $\begin{array}{l}\text { No. of } \\
\text { Patients }\end{array}$ & $\begin{array}{l}\text { Acetylcholine Level } \\
(\gamma / 100 \mathrm{ml} .)\end{array}$ & $\begin{array}{l}\text { No. of } \\
\text { Patients }\end{array}$ & $\begin{array}{l}\text { Acetylcholine Level } \\
(\gamma / 100 \mathrm{ml} .)\end{array}$ \\
\hline $\begin{array}{c}1 \\
6 \\
10(50 \%) \\
3 \\
\text { Average }\end{array}$ & $\begin{array}{l}0 \\
3 \cdot 5-4 \cdot 5 \\
5 \cdot 0-7 \cdot 0 \\
7 \cdot 5-9 \cdot 0 \\
5\end{array}$ & $\begin{array}{l}3 \\
1 \\
1\end{array}$ & $\begin{array}{l}\mathbf{0} \\
\mathbf{1} \\
\mathbf{3}\end{array}$ \\
\hline
\end{tabular}

No acetylcholine could be demonstrated in the samples of cerebrospinal fluid taken during operations for herniated intervertebral disc.

Table III sets out data concerning the pathologyg

TABLE III

TYPE OF LESION, OPERATIVE PROCEDURE, ACETYLCHOLINE LEVEL, AND STATE OF CONSCIOUSNESS OF OPERATED PATIENTSCW

\begin{tabular}{|c|c|c|c|c|c|}
\hline \multirow[t]{2}{*}{ Case No. } & \multirow[t]{2}{*}{ Diagnosis } & \multirow[t]{2}{*}{ Operation } & \multicolumn{2}{|c|}{ Acetylcholine Level $(\gamma / 100 \mathrm{ml})}$. & \multirow[t]{2}{*}{ State of Consciousness } \\
\hline & & & Before Operation & After Operation & \\
\hline 1 O.H. & $\begin{array}{l}\text { Glioblastoma multiforme, } \\
\text { right temporal }\end{array}$ & $\begin{array}{l}\text { Incomplete } \\
\text { removal }\end{array}$ & 3 & $3 \cdot 5$ & $\begin{array}{l}\text { Conscious immediately after } \\
\text { operation }\end{array}$ \\
\hline 2 P.I. & $\begin{array}{l}\text { Glioblastoma multiforme, } \\
\text { left frontal }\end{array}$ & Partial removal & & $8 \cdot 5$ & $\begin{array}{l}\text { Operated in coma, remaing } \\
\text { comatose }\end{array}$ \\
\hline 3 A.H. & $\begin{array}{l}\text { Astrocytoma, grade III, } \\
\text { right temporal }\end{array}$ & $\begin{array}{l}\text { Incomplete } \\
\text { removal }\end{array}$ & & 9 & Clouded for 24 hours \\
\hline 4 S.S. & $\begin{array}{l}\text { Astrocytoma, grade III, } \\
\text { left occipital }\end{array}$ & $\begin{array}{l}\text { Incomplete } \\
\text { removal }\end{array}$ & & 6 & $\begin{array}{l}\text { Conscious immediately aftr } \\
\text { operation }\end{array}$ \\
\hline 5 H.J. & $\begin{array}{l}\text { Astrocytoma, grade III, } \\
\text { left parieto-occipital }\end{array}$ & $\begin{array}{l}\text { Incomplete } \\
\text { removal }\end{array}$ & & 5 & Clouded for two to three days \\
\hline 6 S.R. & $\begin{array}{l}\text { Astrocytoma, grade I, } \\
\text { left frontal }\end{array}$ & $\begin{array}{l}\text { Incomplete } \\
\text { removal }\end{array}$ & $\mathbf{0}$ & 7 & $\begin{array}{l}\text { Conscious immediately atur } \\
\text { operation }\end{array}$ \\
\hline 7 K.S. & $\begin{array}{l}\text { Falx meningioma, left } \\
\text { frontal }\end{array}$ & Complete removal & & $4 \cdot 5$ & Clouded for 24 hours \\
\hline $8 \mathrm{~J} . S$. & Parasagittal meningioma & Complete removal & $\mathbf{0}$ & 4 & $\begin{array}{l}\text { Conscious immediately, but } \\
\text { severe organic mental syndrome } \\
\text { for several days }\end{array}$ \\
\hline 9 S.O. & $\begin{array}{l}\text { Olfactory groove, } \\
\text { meningioma }\end{array}$ & Complete removal & & 5 & $\begin{array}{l}\text { Unconscious before and after } \\
\text { operation }\end{array}$ \\
\hline 10 B-M.S. & $\begin{array}{l}\text { Olfactory groove, } \\
\text { meningioma }\end{array}$ & Complete removal & & $6 \cdot 5$ & $\begin{array}{l}\text { Conscious immediately, but } \overline{\bar{O}} \\
\text { severe organic mental syn- } \\
\text { drome for more than a week }\end{array}$ \\
\hline 11 N.B. & $\begin{array}{l}\text { Meningioma, right middle } \\
\text { fossa }\end{array}$ & $\begin{array}{l}\text { Incomplete } \\
\text { removal }\end{array}$ & & 4 & $\begin{array}{l}\text { Conscious immediately after으 } \\
\text { operation }\end{array}$ \\
\hline 12 K.F. & $\begin{array}{l}\text { Tuberculum sellae } \\
\text { meningioma, recurrent }\end{array}$ & $\begin{array}{l}\text { Incomplete } \\
\text { removal }\end{array}$ & & 6 & $\begin{array}{l}\text { Conscious immediately after을 } \\
\text { operation }\end{array}$ \\
\hline 13 Z.E. & Craniopharyngioma & Partial removal & & $7 \cdot 5$ & $\begin{array}{l}\text { Conscious immediately after } \\
\text { operation }\end{array}$ \\
\hline 14 F.A. & $\begin{array}{l}\text { Ganglion neuroma, third } \\
\text { ventricle }\end{array}$ & Complete removal & $\mathbf{0}$ & 0 & $\begin{array}{l}\text { Severely clouded for } 48 \mathrm{hr} \\
\text { cleared up during } 48 \mathrm{hr} \text {. later }\end{array}$ \\
\hline 15 S.H. & Malignant pituitary adenoma & $\begin{array}{l}\text { Partial right frontal } \\
\text { lobectomy with } \\
\text { partial removal of } \\
\text { tumour }\end{array}$ & & $5 \cdot 5$ & $\begin{array}{l}\text { Comatose before and after? } \\
\text { operation }\end{array}$ \\
\hline 16 Z.H. & $\begin{array}{l}\text { Chromophobe pituitary } \\
\text { adenoma }\end{array}$ & Partial removal & & 5 & $\begin{array}{l}\text { Severe organic mental syn- } \\
\text { drome both before and afterô } \\
\text { operation }\end{array}$ \\
\hline 17 O.H. & $\begin{array}{l}\text { Chromophobe pituitary } \\
\text { adenoma }\end{array}$ & Partial removal & & $6 \cdot 5$ & $\begin{array}{l}\text { Conscious immediately after } \text { 을 } \\
\text { operation }\end{array}$ \\
\hline 18 I.Z. & $\begin{array}{l}\text { Abscess, right fronto- } \\
\text { parietal }\end{array}$ & $\begin{array}{l}\text { Removal with } \\
\text { capsule }\end{array}$ & & 5 & $\begin{array}{l}\text { Comatose for } 72 \text { hr. then } \\
\text { gradually improving }\end{array}$ \\
\hline 19 K.R. & Abscess, left frontal & $\begin{array}{l}\text { Puncture and } \\
\text { evacuation }\end{array}$ & & $3 \cdot 5$ & $\begin{array}{l}\text { Comatose before operation, } \\
\text { regained full consciousness with- } \\
\text { in } 24 \mathrm{hr} \text {. }\end{array}$ \\
\hline 20 P.A. & & $\begin{array}{l}\text { Right frontal } \\
\text { exploratory } \\
\text { craniotomy }\end{array}$ & $1 \cdot 0$ & 3.6 & $\begin{array}{l}\text { Conscious immediately after } \\
\text { operation }\end{array}$ \\
\hline
\end{tabular}


and site of the lesions in the operated patients, type of operation, level of acetylcholine, and state of consciousness of the patients after operation.

\section{DISCUSSION}

The animal experiments demonstrated the presence of free acetylcholine in the cerebrospinal fluid after brain operations. The level found post-operatively was even higher than reported by Bornstein (1946) and Tower and McEachern (1948) after closed head injury. However, this difference may be attributed to the different sources of cerebrospinal fluid, our samples being drawn by cisternal puncture whereas those of the authors quoted were drawn from cerebrospinal fluid after lumbar puncture. A similar increase in the acetylcholine content of the cerebrospinal fluid was shown after intracranial operations in man. Comparison between pre- and post-operative levels indicates that the rise is due to operative trauma: anaesthesia has no effect on the level of acetylcholine.

We can offer no explanation for the variations in the levels of acetylcholine found in our series, both experimental and clinical. In animal experiments, standard surgical procedures in identical areas of the brain produced marked differences in acetylcholine levels. We cannot therefore attribute these variations to the site of operation or to different degrees of operative trauma.

Another problem was that of correlation between the acetylcholine level and the state of consciousness of the patient after operation. Tower and McEachern (1948) claim to have found such a correlation after craniocerebral trauma. Sachs (1957) found that clinical improvement of patients after head injury coincided with reduction of the level of acetylcholine. Bornstein (1946) and Ruge (1954) could reproduce a state similar to concussion by introducing acetylcholine into the cerebrospinal fluid system. These reports seem to infer that acetylcholine has a causative role in producing the clinical syndrome of concussion, the severity of which may be related to the level of acetylcholine in the cerebrospinal fluid. Our results do not confirm this. As already mentioned, the levels of acetylcholine found after trauma were in the range of 1 to $2 \gamma$ per $100 \mathrm{ml}$. (Sachs, 1957) whereas the levels found after operation, with only one exception, were much higher. Only in one case did a high level of acetylcholine coincide with clouded consciousness; in no other case was any relationship found between the level of acetylcholine and the post-operative course of the patient. In our small series the most important single factor for the post-operative state of consciousness seems to be the region of brain involved by operation and the underlying pathological process. Following head injury there are changes in the blood-brain barrier (Grachtenkov, Irguer, Kassil, Veyne, and Kamenetskaya, 1959; Cassen and Neff, 1960; Kassil, 1961; Ommaya, Rockoff, Baldwin, and Friauf, 1964). It is possible that, whatever the mechanism of acetylcholine release, it is only one of several substances which occur in the cerebrospinal fluid after any form of trauma to the brain. We therefore doubt the major role attributed to this neurohormone after head injury.

\section{SUMMARY}

Free acetylcholine was demonstrated in the cerebrospinal fluid of cats subjected to brain operations and of patients who underwent various intracranial procedures. The levels of acetylcholine found were considerably higher than those reported by others after cranio-cerebral trauma, both in animal and man.

No relationship was found between the level of acetylcholine in the cerebrospinal fluid and the state of consciousness of the patient following brain surgery.

Doubts are raised as to the role of acetylcholine in the clinical syndrome of concussion.

Grateful acknowledgment is made to Professor F. Bergmann, Head of the Department of Pharmacology, for his valuable help, and to Professor A. J. Beller, Head of the Department of Neurosurgery, for his advice and criticism.

\section{REFERENCES}

Baldauf, H., and Göhring, K. (1960). Die anticholinergische Behand lung bei Schädel-Hirntraumen. Med. Welt. (Stuttg.), 36, 1887-1889.

Bornstein, M. B. (1946). Presence and action of acetylcholine in experimental brain trauma. J. Neurophysiol., 9, 349-366.

Cassen, B., and Neff, R. (1960). Blood-brain barrier behavior during temporary concussion. Amer. J. Physiol., 198, 1296-1298.

Grachtenkov, N. I., Irguer, I. M., Kassil, G. N., Veyne, A. M., and Kamenetskaya, B. I. (1959). Contribution à l'argumentation de la thérapie pathogénique dans la traume crânio-cérébrale. (In Russian; French summary). Zh. Neuropat. Psikhiat., 59, 351-356.

Heppner, F., and Diemath, H. E. (1958). Klinische Erfahrungen mit der anticholinergischen Behandlung des gedeckten Schädelhirntraumas. Mschr. Unfallheilk., 61, 257-265.

Jenkner, F. L. (1956). Zur Diagnose des geschlossenen Schädelhirntraumas. Wien. Klin. Wschr., 68, 474-476.

Kassil, G. N. (1961). The blood-brain barrier in certain physiological and pathological states of the central nervous system. Sechenov physiol. J. USSR., 47, 333-343.

Ommaya, A. K., Rockoff, S. D., Baldwin, M., and Friauf, W. S. (1964). Experimental concussion. A first report. J. Neurosurg., 21, 249-265.

Ruge, D. (1954). The use of cholinergic blocking agents in the treatment of cranio-cerebral injuries. Ibid., 11, 77-83.

Sachs, E. jr. (1957). Acetylcholine and serotinin in the spinal fluid. Ibid., 14, 22-27.

Tower, D. B., and McEachern, D. (1948). Acetylcholine and neuronal activity in craniocerebral trauma. J. clin. Invest., 27, 558-559.

Ward, A. jr. (1950). Atrophine in the treatment of closed head injury. A. Neurosurg., 7, 398-402.
J. (1950). Atrophine in th 